\title{
Article
}

\section{Ethnicity, opportunity, and upward mobility: Korean entrepreneurship in the Argentine garment industry 1965-2015}

\author{
Kim, Jihye
}

Available at http://clok.uclan.ac.uk/24846/

Kim, Jihye ORCID: 0000-0002-4254-7114 (2020) Ethnicity, opportunity, and upward mobility: Korean entrepreneurship in the Argentine garment industry 1965-2015. Asian Ethnicity, 21 (3). pp. 373-392. ISSN 1463-1369

It is advisable to refer to the publisher's version if you intend to cite from the work. http://dx.doi.org/10.1080/14631369.2018.1548901

For more information about UCLan's research in this area go to http://www.uclan.ac.uk/researchgroups/ and search for < name of research Group>.

For information about Research generally at UCLan please go to http://www.uclan.ac.uk/research/

All outputs in CLoK are protected by Intellectual Property Rights law, including Copyright law. Copyright, IPR and Moral Rights for the works on this site are retained by the individual authors and/or other copyright owners. Terms and conditions for use of this material are defined in the policies page. 


\title{
Ethnicity, Opportunity, and Upward Mobility: Korean Entrepreneurship in the Argentine Garment Industry 1965-2015
}

\author{
Jihye Kim*
}

\begin{abstract}
Currently, among the approximately 20,000 ethnic Koreans living in Argentina, an estimated 80\% are engaged in the garment industry. Within the theoretical frameworks of immigrant entrepreneurship, this research examines why and how Korean Argentines have been continuously concentrated in the clothing industry from the beginning of Korean immigration in the 1960s to the present. Based on ethnographic research conducted in Argentina and on archival and documentary research, this study illustrates how Korean immigrant community in Argentina has settled and achieved upward mobility in the face of complex and fluctuating social and economic circumstances, combining opportunities with strategies and resources to create comparative advantages and benefits. By combining historical contextualisation with theories on immigrant entrepreneurs that had previously only been tested on short-term study periods, findings further suggest that scholars should pay closer attention to historical shifts and accounts in analysing longer-term periods of ethnic business.
\end{abstract}

Keywords: Korean Immigrant Entrepreneurship, Argentine Garment Industry, Ethnic Resources, Opportunity, Upward Mobility

\section{Introduction}

Currently, among the approximately 20,000 ethnic Koreans living in Argentina, an estimated 80\% are engaged in the garment industry. ${ }^{1}$ In the late 1960s Korean immigrants began their involvement in the garment manufacturing sector as humble self-employed subcontractors, gradually developing bigger businesses over time. Since the mid-1980s, they have attained a leading position in the middle-range garment market by managing both production and distribution and by expanding their businesses from the capital, Buenos Aires, to the rest of the country. ${ }^{2}$

Classic works in immigration studies demonstrated high rates of self-employment among immigrant groups in the United States and Europe. These findings stimulated intensive research on immigrant entrepreneurship. In order to understand why immigrants have a high rate of selfemployment in many Western countries, scholars in sociology and geography have developed a range of theories and concepts on immigrant entrepreneurship. Korean immigrants seem to have not been an exception in terms of this high self-employment rate; their businesses, from liquor shops to sushi restaurants, have been ubiquitous in diverse Western countries, such as the US, Canada, Australia and New Zealand. At first glance, Koreans in Argentina have seemed to follow a similar route to those Koreans in other countries, with a high percentage of self-employment.

Many Korean immigrants began their lives in Argentina by taking on machine sewing or knitting jobs as self-employed businesspeople, then gradually expanded their businesses to the commercial apparel sector by opening wholesale or retail shops. Even the most successful Korean businessmen typically acknowledge their transit through machine sewing or knitting in the early stages of settlement. ${ }^{3}$ Because of the profits entailed in these commercial activities, this kind of shift has been viewed as a mark of upward social mobility. Many Korean Argentines in the garment industry unequivocally report similar career paths and business development experiences in Argentina. Often they intend to eventually hand over their businesses to their children, who are 1.5- or second-

\footnotetext{
*Author: Jihye Kim, Lecturer in Korean Studies, School of Language and Global Studies, University of Central Lancashire. Address: AB147, Adelphi Building, Preston, Lancashire, PR1 2HE, UK. Email: JKim22@uclan.ac.uk
} 
generation immigrants. Indeed, many of these children view the opportunity of inheriting the family business as their privilege.

In fact, the garment industry has functioned as a distinctive gateway to economic integration into the host society for a half century, not only for the first generation of Korean immigrants but also for succeeding generations of Korean Argentines. Instead of diversifying their economic activities and fully incorporating themselves into mainstream society, most ethnic Koreans have remained closely tied to an ethnocentric industry. Although there are similarities between Korean entrepreneurs in Argentina and self-employed immigrants elsewhere, this longstanding and enduring affinity with the garment industry has become the distinguishing characteristic of Koreans in Argentina.

Therefore, considering this particular feature of Korean Argentines, this research aims to investigate why and how Korean Argentines have been continuously concentrated in the garment industry from the beginning of Korean immigration to the present. Within the theoretical frameworks of immigrant entrepreneurship, this study seeks to explore what the main factors are that have influenced Korean Argentines' entry into and business development in the Argentine garment industry and how those factors have changed over time, in order to understand the main motivations for Korean Argentines to remain in the garment industry over the last 50 years.

For this research a total of 77 interviews were conducted, in Korean or Spanish. The main participants were active Korean Argentine entrepreneurs, but I intentionally included retired entrepreneurs, employees, and members of other ethnic groups, all of them with different trajectories within the garment industry. The interviews usually took one to two hours, though sometimes stretching to three hours or even longer. I primarily relied on biographical interviews which encouraged the participants to tell their life stories freely; as they talked, I endeavoured to guide them towards the research questions, while paying close attention to the specific issues and factors that the interviewees themselves considered crucial. I applied additional research methods, such as archival research at the office of the Korean Times newspaper in Buenos Aires and an examination of online resources related to Korean associations and garment companies; those sources were helpful to understand the development of Korean garment businesses, identify the main differences and compare past and present conditions.

To present the relevant changes vis-à-vis Korean entrepreneurship in the Argentine garment industry over the last 50 years, I have organised and classified my field data into three categories: (1) subcontracted knitting and sewing jobs in the garment production sector in the 1960s and 1970s; (2) expansion to the garment distribution sector in the 1980s and 1990s; (3) the concentration within the Avellaneda wholesale market in which both production and distribution were undertaken in the $21^{\text {st }}$ century; and 4) younger generation Korean Argentines in the Argentine garment industry and their social integration trends. These four categories facilitate an analysis of how the primary factors and issues affecting the involvement of Korean Argentines in the garment industry have changed and evolved.

\section{Theoretical Framework}

The three main classical theories on immigrant entrepreneurship are Ivan Light's concept of class and ethnic resources, ${ }^{4}$ Edna Bonacich's theory on middleman minorities, ${ }^{5}$ and Alejandro Portes's argument about the formation of ethnic enclaves. ${ }^{6}$ These theories have significantly influenced the ways in which problems and issues involving immigrant entrepreneurs are framed and have been extensively applied to other case studies in Western countries. However, assuming that both migrants and hosts operate their businesses in homogeneous environments, they often neglect the peculiarities of the social, economic and political environments of the host country, focusing narrowly on migrants' individual or ethnic characteristics, such as networks or social capital. ${ }^{7}$

By contrast, more recent theories formulated by Kloosterman and Rath have identified problems deriving from an overemphasis on co-ethnic social and cultural networks in the international literature on immigrant entrepreneurship. ${ }^{8}$ As an example, they consider a focus on immigrant "embeddedness" in terms of individual or ethnic characteristics as a one-sided view on the matter. To correct this limited view, they propose a broader framework of "mixed embeddedness". This concept recognises 
the crucial significance of immigrant social capital and ethnic resources in the entry into and operation of immigrant enterprises, but also places them together with the wider social, economic and political contexts of the host country as explanatory factors. ${ }^{9}$ While this approach is related to the earlier theory of "structure of opportunities", which focuses on market positions and dimensions, ${ }^{10}$ the new construct suggests that a more comprehensive examination of frameworks should include laws, regulations, institutions, governmental practices, and broader economic environments which considerably affect the ways in which markets operate.

Among those diverse theories on immigrant entrepreneurship, the concept of mixed embeddedness has been particularly important in this research. This concept emphasises the significance of immigrants' concrete embeddedness within social networks and opportunity structures that are closely related to the broader social, economic and political contexts in the host country. This theory claims that opportunities for ethnic entrepreneurial activities are placed at the intersection of factors and changes pertinent to the economic, institutional and socio-cultural transformations in the host country, with a particular emphasis on the crucial interplay and dynamics between immigrants and the larger contexts in which they are embedded. Although ethnic resources and other micro factors are critical, the environment in which entrepreneurs operate can be significantly influential; indeed, it may equally contribute to the determination of the shape and dynamics of business practices and of their effective success.

Many sociological studies have demonstrated the important role immigrants have played in the development of the garment industry globally. ${ }^{11}$ The vast majority of research, however, has been confined to immigrant entrepreneurs, their workforce, and their informal activities strictly within the garment manufacturing sector.

In Argentina, the apparel industry is one of the largest informal sectors. However, the contexts and conditions within which the Argentine clothing industry exists are quite different from those in developed countries, showing a high level of informality not only in production but also in the commercial sector. A considerable number of Korean entrepreneurs in Argentina operate retail or wholesale clothing businesses in the commercial sector. Specifically, Korean wholesalers undertake complex operations - from design and manufacture to distribution - independently. In recognition of these distinctive features of the Argentine garment industry, I have paid closer attention to analysing the structure of the industry and its informal characteristics. In particular, I have used and applied the concept of mixed embeddedness to understand the Korean immigrants' entry into the informal sector, which provides a better "niche market" than the formal sector.

Furthermore, Argentina is a developing country with a successful past but a difficult present, particularly in terms of economic progress. In developing countries, cycles of growth and recession tend to sharply fluctuate and to have critical consequences for economic activities. Specifically, the local economic environments in which ethnic Koreans have developed their businesses to optimise middle- and working-class consumption patterns have experienced tremendous instability and sharp fluctuations. Argentina's complex, dynamic economic evolution has affected the garment industry substantially, swiftly opening niches and just as abruptly closing them in unusually powerful sequences and cycles. Thus, the concept of mixed embeddedness has allowed me to focus on those particular macro-economic contexts that have influenced the entry and development of Korean garment businesses in Argentina.

Taking into account the particular characteristics of Korean garment businesses and the distinctive economic environment of Argentina, I have applied the concept of mixed embeddedness to my analysis, focusing on three dimensions: (1) individual and ethnic resources; (2) the opportunity structure of the Argentine clothing industry; and (3) the wider social, economic and political environments, in particular domestic economic trends in Argentina.

However, considering the limitations of using mixed embeddedness as the sole basis of a theoretical framework, I apply this theory more broadly, incorporating other concepts such as labour market disadvantage, ethnic and class resources, social capital, and opportunity structure, in order to explore, as widely as possible, the factors and issues that have interacted to affect the emergence, consolidation and evolution of the Korean garment business. Applying other conceptual frameworks, I further examine how those factors directly or indirectly connect with other key social dimensions of mixed embeddedness theory, in order to better examine the ways in which Koreans in Argentina have embedded themselves in their host society. 
One of the most relevant factors, repeatedly stressed during the interviews with Korean immigrants, was changes and shifts over time. Although Korean immigrants have been continuously involved in the garment industry, their businesses in Argentina today are strikingly different from those in the initial stages of Korean immigration there, in terms of business scale, type, management styles and other related issues. For instance, while my interviewees and informants tended to relate their stories and experiences in chronological order, they repeatedly stressed the differences between the past and the present, as well as the issues relevant in each specific period through which they had lived. However, until now, no theory on immigrant entrepreneurs, including the concept of mixed embeddedness, has considered historical shifts and accounts because most empirical cases have only been tested for a short-term period. For this reason, and with the goal of contributing to bridging a current gap, I have favoured a new approach that combines existing theories with historical contextualisation, rather than simply apply existing theories in my data analysis process, thus helping analyse and trace different factors related to the Korean entrepreneurship throughout the half century and overcoming the lack of historical perspectives of previous theories on immigrant entrepreneurship.

\section{From Agriculture to Apparel: The Entry of Koreans into the Argentine Garment Industry (1960s-1970s)}

The first Koreans immigrated to Argentina in 1965 as part of a governmental program to increase the country's agricultural production. They were settled in the province of Rio Negro in southern Argentina and given previously unworked land to open up. ${ }^{12}$ However, as the Korean migrants were mostly of a white-collar background, they struggled with the work involved in establishing and running farms. Despite support and encouragement from the Korean government, a lack of sufficient economic resources and experience in agricultural production and business led to feelings of maladjustment, resentment, and unhappiness with their lives in Rio Negro. ${ }^{13}$ Consequently, the majority of these early Korean immigrants gave up on farm ownership in southern Argentina and left for the capital, Buenos Aires. ${ }^{14}$ Their failure to pursue rural agrarian life ended up revealing a new opportunity for them and for those that would follow. Irrespective of their former social and economic backgrounds, most Korean immigrants who resettled in poor neighbourhoods of Buenos Aires began their new lives as unskilled workers, such as dishwashers, waiters, street-corner grocers selling vegetables and fruits.

In an extraordinary bit of serendipity, the garment knitting and sewing jobs were spotted by Korean immigrants after settling in Buenos Aires. According to Lee, a Korean female immigrant with previous home-country experience in machine knitting found that immigrants like herself could earn money as machine-knitters subcontracted by non-Korean immigrants, most of them related to the earlier-established Jewish business community. ${ }^{15}$ This pioneering woman and her husband taught other immigrants how to operate knitting machines and distributed tasks among other immigrants. This community training was popular among female immigrants, since after only a week of practice, they could immediately start earning an income and thus help their families. Initially, female immigrants supplemented male immigrants' income through home-based machine knitting work (pyeonmul). Eventually however, male immigrants joined in managing the larger knitting machines (yoco).

Beginning in 1968, Korean immigrants also became involved in machine sewing. ${ }^{16}$ Unlike the noisy machine knitting that attracted complaints from neighbours, machine sewing was a quiet, more agreeable job to conduct in the family home. According to Lee, Korean immigrants concentrated on machine knitting work from 1967 to 1975 . Sewing subcontracted work became more popular after $1975 .{ }^{17}$

Newly arrived groups usually encounter a variety of difficulties in socially and economically integrating into their host countries. ${ }^{18}$ For example, finding employment in host contexts can be particularly challenging when immigrant groups are disadvantaged due to a language barrier or ethnic/racial discrimination, among other factors. As most of my interviewees also emphasised, the language barrier was the main factor in determining self-employment as the point of entry for most new immigrants in Argentina. Specifically, many immigrants claimed to have started garment sewing and knitting jobs because they did not require any language skills, as illustrated in the interview 
below, 'The main reason was language. Japanese [immigrants] started laundry business, because it did not require language skills: only clean the clothes and return them to the clients. Making clothes is the same. They didn't need any language skills. Korean [immigrants] started clothing business because it didn't require any language skills'.

Numerous similar stories indicate that language was the primary challenge that led early immigrants in the 1960s and 1970s into garment sewing and knitting work. Further examples include, 'It took almost 10-15 years until Koreans started to open [retail/wholesale] garment shops. Language is the reason why the Korean community did sewing and knitting jobs for such a long time. Without knowing the language how could we know the regulations to open legal business? Language was the most important factor that determined that many Koreans took sewing and knitting jobs in the 1960s and 1970s'.

As suggested in the above interviews with the early Korean immigrants of the 1970s, the language barrier as a major push factor has been presented in most interviews with Korean immigrants regardless of their arrival date - for those who arrived in Argentina in the 1960s and 1970s, but also for those coming in the later stages.

Furthermore, since Korean immigrants did not speak the local language, they depended heavily on other Korean immigrants to solve basic matters, such as renting houses and getting jobs. Reliance upon the Korean community was the natural or sometimes the necessary path to earn a livelihood and to make a life in Argentina. This adaptation process included sharing business information, job opportunities, training and skills, among other resources. As the following interviews illustrate, Korean immigrants highly depended on ethnic networks in the early stage of their settlement in Buenos Aires: 'In Seoul my family had run a shop that sold kitchenware. They didn't know anything about sewing machines. My father knew some Korean acquaintances who had arrived earlier. Through their help, they bought some sewing machines and learned the job'. 'We first went to Santiago del Estero [Argentina] with an agricultural project in 1979. After living there for a year and having many hardships, we moved to Buenos Aires. We worked for a Korean lady who offered us food and lodging. There were five families there. The house lady brought work and distributed it to us. After working there several months and learning the sewing skills, we became independent and started our own workshop'.

Moreover, use of the family labour force influenced Koreans to choose the garment sector and to become competitive and successful entrepreneurs. Operating a family-based workshop was usually the first job on the economic ladder, a critical pathway to accumulate capital and move upward into another business. Buoyed by the family-owned business model, an ethic of hard work and effective use of reliable community networks, Korean immigrant businesses grew rapidly in the 1970s.

Other studies confirm that the garment industry is attractive to immigrants because it offers a variety of jobs that easily accommodate their conditions. ${ }^{19}$ Particularly, as garment sewing and knitting work is regarded by the host society as lowly, it is usually available to immigrants and poses little barrier for entry into the labour market. For instance, a significant number of Koreans in the US easily got involved in garment sewing jobs in the immediate period after migration because members of the host society tended to shun such jobs. ${ }^{20}$ Likewise, some of my interviewees suggested that Argentine people were reluctant to take on sewing and knitting jobs, leaving them within easy reach of those first Koreans in Argentina, who soon created for themselves a niche in the sector.

The relatively small capital investment to start a garment sweatshop - such workshops required small workspaces and a few relatively inexpensive machines - was another important source of motivation for many Koreans to engage in the sector. After working in humble sewing and knitting jobs for several years, they saved up adequate funds to start up their own businesses. This proved an agreeable, accessible, and clear path towards steadily improving their economic situation. Some became independent manufacturers or wholesalers in their own right, and some moved to another sector to run different types of businesses, such as grocery businesses.

In his book, Lee presents the results of a 1976 report by the Korean embassy in Buenos Aires on immigrant occupations. ${ }^{21}$ The table below, taken by Lee from that report, clearly demonstrates that 75-80\% of Korean immigrants in Argentina were engaged in knitting and sewing subcontracting / manufacturing businesses. It also indicates that a substantial number of immigrants (18\%) worked in the commercial and services sectors, particularly small grocery businesses. ${ }^{22}$ 
Table 1. Korean immigrant occupations in $1976^{23}$

\section{From Production to Distribution: Expansion of the Korean Garment Business (1980s-1990s)}

By undertaking low-status sewing and knitting jobs during the 1960s and 1970s, Korean immigrants established a secure economic foothold in the Argentine garment industry. In the 1980s, Korean immigrants started opening wholesale or retail shops based on the know-how they had acquired in the previous stages and on the economic advantages they had in the sector.

As in the previous stage, small Korean workshop owners - leveraged by family and ethnic labour, hard work, discipline, and the effective use of reliable community networks - made notable economic progress in the 1980s and 1990s. As in the previous stage, leveraged by family and ethnic labour, hard work, discipline, and the effective use of reliable community networks, small Korean workshop owners made notable economic progress in the 1980s and 1990s. However, compared to the previous stage, one of the distinctive changes in Korean workshops was a shift in the primary labour force. My field data suggests that Korean immigrants initially conducted machine sewing and knitting jobs in the 1970s. However, eventually, with the increasing demand for production and the growth of their workshop scale, Korean entrepreneurs began recruiting workers from outside their ethnic group; mainly undocumented Bolivian or Paraguayan immigrants for low-paying knitting and sewing jobs. Later, Bolivian immigrant labour came to be preferred over other Latin American workers, as the Korean entrepreneurs believed Bolivians had a better "attitude". ${ }^{24}$

Since the early days of Korean immigration, many of those small manufacturers personally visited retail shops in the greater Buenos Aires metropolitan area to sell their own lines of clothing. However, since the 1980s, Koreans started opening wholesale shops in the Once neighbourhood of Buenos Aires or retail shops in the provinces; thus, Korean independent manufacturers sold clothing directly to Korean wholesalers or retailers in larger quantities in their clothing factory.

Korean independent manufacturers were engaged exclusively in garment production: designing, producing and supplying apparel to Korean retailers or wholesalers. These plants were invisible inhome factories; they were neither formally operated nor open to non-Koreans. Only Korean immigrants had information and access to these Korean manufacturing plants through the community networks, so they were highly regarded as a hidden driving factor to supply ready-made-clothing to Korean wholesalers and retailers. For Korean wholesalers who did not have the experience and knowledge of clothing manufacturing, these suppliers were crucial, because these invisible factories allowed them simply to buy and re-sell ready-made garments to local retailers. Korean retailers in the provinces also bought clothes directly from these co-ethnic manufacturers thus bypassing wholesalers; they thereby obtained clothing at wholesale prices and sold them with a higher profit margin. This cooperation helped new Korean entrepreneurs to compete with established Argentine wholesalers and retailers. The following interview comments reflect the comparative advantages that those Korean manufacturers provided for their fellow Korean retailers and wholesalers: 'Those factories provided clothes exclusively to Korean wholesalers or retailers. It was a driving force allowing Korean immigrants to open retail or wholesale garment shops easily, particularly for those who didn't have any previous experience in garment making, like myself'. 'Those manufacturers played the middlemen role between Korean garment wholesaler and retailers. At nighttime, many Korean retailers visited our factory to buy clothes, because if they avoided wholesalers, they got higher profit margins. Argentine retailers bought from Korean wholesalers in Once during the daytime. I mean Argentine retailers had to go through one more step and got smaller margins'.

Moreover, Light and Gold suggested that co-ethnic support in terms of financing plays a particularly vital role for immigrant entrepreneurs, because such funding was the most important source of accessible financial capital beyond personal savings. ${ }^{25}$ For example, in his study, Yoon demonstrated that Korean entrepreneurs in Chicago depended on several co-ethnic loan sources to initiate their businesses: 35\% from kin, 19.9\% from friends, 13.7\% from Korean American banks, and $27.9 \%$ from gye funds (Korean rotating credit system) ${ }^{26}$ In a similar way, some Korean entrepreneurs in Argentina emphasised the support of their family, while others acknowledged that the help of close friends, particularly financial assistance, was crucial in the initial stages of their businesses, as in the 
example below: 'My business failed in Korea. When I came here in 1994, I had a $\$ 100,000$ [US] dollar debt. A friend of mine, who was well settled and who ran a successful garment wholesale business, recommended that I open a retail shop in suburban Buenos Aires lending me \$100,000 [US] dollars. My new business here was successful, so in two years, I could make $\$ 200,000$ [US] dollars and paid back all my debts'.

Besides, gye, the informal rotating saving system used by community members, aided the expansion of Korean retail/wholesale garment shops and stimulated upward mobility for many Korean entrepreneurs in Argentina. Other credit systems, such as private loans, credits, and post-dated cheques, were frequently used between wholesalers/manufacturers and retailers as well. However, as those systems were informally operated, they were highly dependent upon the reliability of the members, as the below story reports: 'When I opened this store [in the 1980s], I was taking the money from four different gyes of \$2,000 [US] dollars each. After getting gye money in the first turn, I rented this shop. Of course, I did not have money for the clothes, so I took credits from Korean wholesale shops and factories to buy them. I paid back on time to them, and kept up my credit with them. I also gave the gye money back every month. Without those gye funds and credits from Korean wholesale shops, I wouldn't have been able to open my own [retail] shops. Afterwards, I did gye several times and lent money to my son's friend's mom to help them, but unfortunately in the end, many did not pay me back. After those experiences, I don't lend money to Koreans or do gyes anymore. I lost not only the money but also the people'.

As the above interview illustrated, several negative effects were caused by the high dependence on the ethnic networks and resources within the community. Keen competition among the co-ethnics who ran the same type of business was another inevitable cost during the rapid development processes. Moreover, the difficult economic contexts in the host country, such as unexpected crises, high inflation, and constant changes in the real value of money aggravated those problems generated by the informal credit systems among Korean immigrants. With the passage of time, the ways of using ethnic resources and the patterns of business management and strategies have evolved and been re-shaped among the Korean community members, with the twin aims of reducing negative side effects and simultaneously more effectively maximising individual profits.

As the table below indicates, the number of Korean-owned retail garment shops in the provinces, outside of the Buenos Aires capital district, increased sharply in the 1980s and 1990s, buoyed by a credit system based on ethnic bonds between Korean retail shop owners and manufacturers/ wholesalers. ${ }^{27}$ Furthermore, Korean retailers sold with a $50 \%$ profit margin, in competition with Argentine retailers who operated with $100 \%$ profit margins. ${ }^{28}$ The resulting intense competition forced most retailers - both Korean and Argentine - to lower their prices and reduce their profit margins. Marketed to middle- and lower-income consumers, the clothing produced by Korean manufacturers was sold in numerous co-ethnic retail stores throughout Argentina. ${ }^{29}$

\section{Table 2. Numbers of Korean garment shops in Argentina ${ }^{30}$}

From 1985 to 1990 , the Korean community's numbers escalated dramatically from 10,000 to 36,000. This remarkable wave was the result of the 1985 agreement on entry and exit procedures for Korean immigrants signed between the governments of Argentina and South Korea. ${ }^{31}$ A condition of the revised act was that Koreans with a minimum of US\$30,000 per family to invest in Argentina were permitted to immigrate. ${ }^{32}$ This reinvigorated immigration brought both the injection of capital and the increase of immigrant entrepreneurs into the Argentinean garment sector.

Furthermore, the idea that informal/semi-formal conditions of the Argentine garment market provided a better "niche market" was repeated over and over in many interviews to explain the easy entry and the fast economic growth of Korean entrepreneurs into the garment commercial sector. The Argentine market can be segmented into four major components: (a) large brands ("big name brands"); (b) small brands ("neighbourhood brands"); (c) massive sales of products at low prices; (d) informal outdoor markets. Apparel production in Argentina exhibits a high level of informality throughout all the segments, as is the case in European and North American countries. ${ }^{33}$ Typically, production is in unregulated sweatshops which are neither registered nor which meet basic health and safety standards. However, in Argentina, while overall the clothing production sector demonstrates an elevated degree of informality, each segment has an identifiable distinctive degree of formality in 
terms of commercialisation, i.e., the "brands" outlets are formal; the massive wholesale area in Once and Flores is semi-formal; and the outdoor markets such as La Salada are extremely informal. As Light pointed out, informal economies provide more accessible market niches to those with minimal resources who seek self-employment. ${ }^{34}$ Many Korean interviewees agreed that the informal conditions not only in the production but also in the commercialisation of clothing offered easy entry opportunities to Korean immigrant entrepreneurs to transfer from sewing and knitting jobs to retail/wholesale businesses in the Argentine garment industry.

Since the early 20th century, Once, a neighbourhood within the City of Buenos Aires, had developed as the center of the Jewish community and the hub of the garment trade. From the late 1970s, Korean immigrants began opening wholesale apparel shops in Once. According to Lee, the fact that Korean immigrants started moving from sweatshops, street vending and small grocery shops to wholesale apparel shops in the Once neighbourhood was significant; to Lee, it meant a step up on the lower- to middle-class ladder within Argentine society. ${ }^{35}$ Furthermore, during the growth period of the Argentine garment industry in the 1990s, ethnic Korean entrepreneurs captured a significant market share, particularly in female fashion apparel. ${ }^{36}$ This was a significant development for the Korean immigrant community, in terms of economic improvement and upward social mobility within Argentine society. ${ }^{37}$

\section{The Korean Garment Business in Argentina Today (2000-Present)}

As briefly mentioned, Korean garment manufacturers (producers) and wholesalers (distributors) operated as separate businesses until the mid-1990s: invisible independent Korean manufacturers supplied ready-made-apparel to co-ethnic wholesalers in the Once neighbourhood. However, by the end of the 20th century, many of those independent manufacturers opened their own wholesale shops around Av. Avellaneda in the Flores district, manufacturing and selling clothing at the same site. Thus, this new competition made it difficult for the already-established wholesalers in the Once neighbourhood for two reasons: first, the number of garment manufacturers who supplied readymade-apparel was declining, providing limited quantity of clothing and increased prices; and secondly, because the older establishments had to compete with new shops around Av. Avellaneda in Flores, directly owned by the very same manufacturers who sold comparable merchandise at better prices. Some of those existing established wholesalers in the Once neighbourhood had to adapt their operations: therefore, they began to move to Av. Avellaneda, manufacture their own clothing directly, and incorporate both production and distribution operations. According to the best available estimates ${ }^{38}$ the new area became a highly commercialised middle-lower price and quality apparel wholesale sector with approximately $30 \%$ of the shops under the control of ethnic Koreans who are primarily producing and selling women's clothing.

Unlike in the previous decades when there was a massive influx of Korean immigrants to Argentina, Korean immigration decreased significantly in the $21^{\text {st }}$ century. Furthermore, after the dramatic economic crisis of 2001, many Koreans left the country. Currently, most Koreans are immigrants who arrived in Argentina in the past decades, with new immigrants arriving infrequently. Early immigrants have established themselves firmly in the host country; they possess significant previous experience and know-how in the garment industry. While most Korean entrepreneurs concentrate in the Av. Avellaneda wholesale market, a minority operates garment workshops, retail shops, and other related businesses. With the economic growth of the sector, some Korean entrepreneurs also became involved in larger-scale activities, such as textile production and imports.

In this contemporary phase, except for some isolated examples from new immigrants, ethnic resources, seem to have lost their centrality in the immigrant story. Today, ethnic Koreans tend to share general or basic information through community newspapers or via several Internet sites provided by the Korean Association or the Chamber of the Korean Entrepreneurs in Argentina. ${ }^{39}$ However, although the ethnic community does not provide direct business information or capital as in the previous stages, it still frequently performs essential functions for new immigrants who seek a job or who start a new business. In addition, Korean entrepreneurs tend to sell their businesses to other 
Koreans; thus, the ethnic community often provides eventual business opportunities. When they need specific business information, they also ask trusted friends or people from the same church for help.

Furthermore, after numerous problems related to unpaid debts among the Korean community members, the dependence on gye or on the extension of co-ethnic credit financing has decreased sharply. Many interviewees, particularly those who are running large-scale businesses asserted that they started operations with only their own money without any loan or credit from others. Although in a few cases, I heard of the use of gye for business purposes, it is primarily used today to promote friendship. Yet, those who received financial help freely admitted that it is still easier to get loans and credits from families or ethnic friends rather than from Argentine acquaintances.

Currently, there are 1,400 Korean wholesale shops (including small shops or kiosks in shopping arcades and malls) among the 3,000 wholesale outlets in the garment wholesale district around Av. Avellaneda. ${ }^{40}$ The number of wholesale shops may be underestimated, as the number of small shops or kiosks is currently increasing. ${ }^{41}$ Korean entrepreneurs attribute their primary motivation to enter into the garment business to the comparative advantages within the sector rather than to ethnic networks and resources. A further attraction of the commercial clothing sector is the diverse array of business opportunities it offers; they are available to both large and small capital investors. In the new decade, shopping arcades or malls (Spanish: galerias) with small shops or stands have been popular; until recently they were still multiplying around Av. Avellaneda. The small shop owners do not produce apparel directly but rather buy clothing from wholesalers and resell them to retailers or individual customers. Those small shops provide opportunities to open businesses without large amounts of capital; thus, this may also encourage many ethnic Koreans to enter the garment business.

The business prospects of Korean entrepreneurs in Argentina have been negatively affected by decades of difficult and fluctuating economic contexts. However, contrary to popular belief, my field data suggest that the unstable and hard economic and market conditions of the host country are not always pessimistically viewed by immigrants as negative influences on Korean garment businesses. As the following interview comments clearly demonstrate, the economic instability and backward market conditions can be viewed as a crucial opportunity to enter a new market easily and to advance rapidly for Korean entrepreneurs: 'Under the well-organised market and society like the US and Korea, it is difficult to break into a new market and to go up easily and fast. However, under the underdeveloped economic structure like Argentina, there are many more possibilities to enter a new market and to succeed, because in the less organised market and society there are more gaps and breaks [niches]. Also, there is much less competition. It provides better conditions to make your business successful'.

While economic crises usually affect business negatively, for those who have enough leverage to overcome difficult economic periods, those crises have been advantageous opportunities to increase the scale of their businesses and prepare themselves for the next step. In addition, for those immigrant entrepreneurs with limited resources, economic crises have also provided an easier gateway to enter the competitive wholesale markets, as the interviewee below experienced: 'I started a wholesale shop with my sister just before the 2001 crisis and one dress model had a big success. When we decided to separate the business, we faced the [economic] crisis. More than half of the shops around Av. Avellaneda were closed and many people left for the US. At that moment, I opened a shop, because I didn't have any other option. People told me that I was crazy. However, I just learned that I could start a business with very little money during the crisis. At that time, there was no key money requirement, the rent was cheap. I re-invested all the profit into buying fabrics during the first years [of my business]. After several big model successes, my [wholesale] business went up continuously. I believe that crisis is an opportunity, because of my experience'.

In particular, the rapid economic recovery in the post-2001 crisis period also accelerated the expansion of Korean wholesale shops around Av. Avellaneda. The phase of economic growth, employment and real wages expansion that the country experienced roughly from 2003 to 2012 evidently benefitted the apparel sector. Thus, many of those I interviewed who are currently operating garment wholesale businesses entered the market in the post-2001 crisis period. They stressed that the rapid growth of the garment wholesale market was related to the recovery of the economy after the 2001 fiscal crisis.

In the meantime, several negative side effects have been identified as many Koreans concentrated in the wholesale sector. In particular, competition has become a pressing issue among Korean 
wholesalers. Moreover, while a considerable number of Koreans have achieved upward mobility, of course, it cannot be applied to all the community members. Certainly, there are some others who remain fixed in the same place or some who have even experienced downward mobility.

As a result of these uneven trajectories, the cleavage between rich and poor grows deeper and wider within the Korean Argentine community, as it did for Argentines as a whole, after the several severe economic crises. In other words, although most of them are physically confined in a specific geographic location and industry sector, Korean entrepreneurs cannot be viewed as a unitary business group: huge differences emerge among community members in terms of economic position, background, life trajectory, and degree of integration into the host society. As the classical theorists of "ethnic and class resources" claimed, while in the initial stage of Korean immigration and involvement in the garment industry ethnic resources played an essential role, today "class" resources appear to have become more significant for Korean businesses. ${ }^{42}$

\section{New Generation Korean Argentines in the Argentine Garment Industry and their Social Integration}

Globally, previous literature on immigrant communities has suggested that although a high proportion of first-generation immigrants operate their own businesses, most succeeding generations change their careers, as their families blend into the mainstream society ${ }^{43}$ This has been the case for younger generation Koreans in the US and other developed economies. ${ }^{44}$ In contrast, a far smaller proportion of Korean Argentines seek their success by pursuing professional careers such as those in medicine, law, engineering, finance, and academia. Instead, they tend to remain in ethnic businesses largely represented by a range of garment ventures, from wholesale or retail shops to clothing factories.

For many first-generation Korean immigrants in Argentina, the garment business provided an accessible entry point into the host country's economy, and one with distinct rewards. Certainly, the reasons why 1.5- and second-generation Korean Argentines might want to engage in a garment business are quite different from those of their first-generation predecessors. Korean Argentines who grew up in Argentina are native Spanish speakers and understand their social environment like any other Argentine.

In order to start a business, entrepreneurs primarily need access to capital and business expertise. Unlike the first generation of Korean immigrants, who were often dependent on ethnic networks to obtain venture capital, the 1.5- and second-generations tend to obtain business information, know-how and initial capital from their families or else take over the family firm to continue developing wholesale or retail enterprises. While, there were a few cases in which young Korean Argentines accepted a small amount of credit from friends or others, usually community members, we did not encounter any cases of young Korean Argentines starting wholesale or retail clothing businesses exclusively on credit, most young interviewees agreed that financial injections from parents are crucial in starting one's own business. If they are unable to obtain economic support from the family, they take on work with other Korean entrepreneurs as employees, usually as shop or factory managers. As illustrated in the following interview with a second-generation Korean Argentine, who ran a retail clothing shop in Buenos Aires, financial injections from his parents were crucial for starting his own business: 'I worked for a big local dairy production company, as an engineer for about two years. I compared my father's income [running a retail shop in Bahía Blanca] to the salary of my boss, who worked more than twenty years as a professional engineer at the company. My father's income was much higher than my boss's. [...] My friends who really wanted to continue their careers went overseas. My wife, who studied odontology, and I decided to stay here because we wanted to be close to our families. We took over my parents-in-law's retail shop in Buenos Aires. My father put up the money to upgrade and improve the building. [...] A clothing business requires a lot of money. It is impossible to save money and gather the initial capital to start a business working on your own. [...] Shop repairs and improvements also require a lot of money. Without family support, it would be very difficult'.

Besides, as in the interview above, Korean Argentines repeatedly expressed the view that the low salaries in Argentina are the crucial factor inclining them towards the family business. In addition, my interview data further confirm that many complex social factors are involved in the decision of 
Korean Argentine youth to pursue the garment business. Particularly, job market circumstances typical of a developing country like Argentina, such as low professional salaries, un- or underemployment, job dissatisfaction, and blocked opportunities, seem to act as push factors towards family businesses or co-ethnic jobs. Thus, as the concept of mixed embeddedness suggests, this trend should be understood as related to the social, economic, and political environments in the host country.

Another possible approach to better comprehend these findings is to analyse the different forms of social capital. While the topic of racism or outward discrimination did not arise much in interviews and conversations, issues around limited social capital in wider society did, as evidenced in the following: 'Children need role models in mainstream society to inspire their future plans outside the garment industry, but available role models are very limited. Ninety-five percent of Koreans are in the garment business, so the odds are that ninety-five percent of our children will run a garment business. I sent my children to the US in order to show them another world. For instance, local Jews have many relatives who have professional jobs, so they can follow those professions naturally. Koreans are too limited'.

Many interviewees from the Korean community held a similar view that Koreans pursuing professional careers have limited opportunities, connections and social capital in the wider job market. According to Portes and Sensebrenner, ethnic minorities are frequently characterised as having tight social networks and beneficial resources. ${ }^{45}$ However, these features can have advantages as well as disadvantages. On one hand, ethnic social networks and resources are often believed to provide security, solidarity and opportunities within the ethnic business community. ${ }^{46}$ On the other hand, ethnic networks and resources are also viewed as negative, thereby hindering economic integration within the host society. ${ }^{47}$ The case of Korean Argentine entrepreneurs demonstrates that favourable class resources (the initial capital and know-how from the family) as well as ethnic resources (strong inter-ethnic ties and information sharing) are beneficial for advantageous business and employment opportunities within the Korean business community; nevertheless, that powerful combination of resources does not necessarily contribute to a better socio-economic position in the larger mainstream Argentine society.

\section{Conclusion}

As many previous scholars in migration studies have emphasised, the unfavourable local labour market, particularly stemming from language barriers in the new country, was the main reason for self-employment of the first generation of Koreans in Argentina. For those in the early stages of immigration, the garment sewing and knitting subcontracted work was one of the most suitable options for the immigrants as it could be carried out without significant language skills or capital investment; this was true for individual workers and those pursuing small business opportunities. Furthermore, co-ethnic networks facilitated the efficient transmission of the necessary skills and distribution of tasks, materials and opportunities. As a result of its labour-intensive nature and vertical structure, the garment industry offered various types of jobs, easy business entry, and dynamic economic opportunities. ${ }^{48}$ As previous studies suggested, these pathways that Korean immigrants undertook in the early stages are quite common and similar to the ways in which many immigrants engage with the clothing production sector in other countries. ${ }^{49}$

Yet, Korean immigrants did not remain in the arduous and financially less rewarding sewing and knitting jobs for very long. Based on the accumulated know-how and capital, and the secure foothold they gained in the sector, Koreans managed to move into the garment wholesale and retail sectors, where bigger returns beckoned. Certainly, Koreans used their ethnic resources and networks effectively, extensively and intensively to enlarge their businesses. For many of the Koreans I interviewed, invisible Korean manufacturing operations and informal co-ethnic credit systems were cited as significant aids for their business expansion into the commercial garment sector. However, in this research, I stress the importance of context in these choices: the particular characteristics of the Argentine garment industry provided Koreans easy entry and rapid upward mobility into the commercial garment sector. 
According to my interviewees, the open structure of the Argentine garment industry, with numerous available niches, provided the essential opportunities and conditions for entrepreneurial Korean immigrants to enter, remain, and/or transit between garment sectors. The Argentine garment industry is characterised by a high rate of informal or semi-formal management structures, not only in apparel production but also in a considerable portion of the clothing distribution sector. This circumstance is quite distinctive from that in other countries; in Argentina, this has translated into a broader array of niches for Korean entrepreneurs to enter the commercial garment sector.

The beneficial macro-economic conditions after the 2001 financial crisis were important drivers influencing Korean business expansion into the wholesale garment sector. During the subsequent phase of rapid economic growth, numerous Koreans initiated complex business operations, undertaking both garment manufacturing and wholesale enterprises. In these ventures, the business scale was enlarged significantly and many attained significant success in the Avellaneda wholesale market. By the turn of the $21^{\text {st }}$ century, while the macro-economic contexts and individual economic power influenced the entry and development of Korean businesses critically, ethnic resources paled in significance compared to the previous decades. Nevertheless, the stories from those successful Korean wholesale businesses indirectly encouraged and motivated other Koreans to enter the wholesale sector.

Unlike second-generation Koreans in other countries, who tended to reject the small-business preferences of their parents and sought to pursue professional careers and to achieve mainstreamoriented mobility, Korean Argentines continued to choose work within the garment industry. The interviews hint that this counter-trend should be understood in the typical economic and social circumstances of a developing country. Primarily, Korean Argentines expressed the view that low professional salaries in Argentina are the crucial factor and the practical reason for the strong business preference of successive generations. Furthermore, for Korean Argentine youth, the typical job market circumstances of a developing country, such as unemployment, underemployment, job dissatisfaction and/or blocked opportunities, seem to have acted as push factors toward family business or co-ethnic job opportunities. Unquestionably, the undeveloped and informal garment market conditions in this developing country provided advantageous opportunities for easy entry and rapid advancement for Korean entrepreneurs; at the same time, the difficult overall conditions of the labour market in Argentina militate against and limit satisfying employment opportunities and economic chances for young Korean Argentines in mainstream society. In summary, the continuous concentration of Korean businesses in the Argentine garment industry is the result of both the positive and negative sides of the social, economic and political environments of this developing country.

So why have ethnic Koreans in Argentina so continuously engaged in the garment industry? In this study, I assert bluntly that, in the difficult and complicated host country context, a considerable number of Koreans achieved upward mobility through available opportunities provided by the garment industry; they accumulated key advantages over time; and most still believe these opportunities and advantages can yield comparative benefits. If a considerable number of Korean immigrants in the garment industry had not been able to achieve this upward mobility, the story would have probably differed.

With regard to the specific factors that influence Korean business development and upward mobility within the garment industry, I certainly found that ethnic networks and resources were used as a strategic tool by Korean entrepreneurs to achieve economic viability, financial support, and eventual upward mobility within the Argentine society. However, as discussed in this research, several intertwining factors were coming to life in the entrepreneurial narratives of Koreans. Some of these factors arose from individual abilities to adapt, while others stemmed from micro- and macroenvironments providing opportunities. In this case, the concept of mixed embeddedness seems a more appropriate framework for focusing on how the micro-level of individual and ethnic variables interface with the macro-level of social-structural factors; the interface of these variables is particularly relevant in the distinctive contexts of a developing country like Argentina.

Finally, although most Korean Argentines have been working in the same sector for half a century, this research shows that the motivations behind their involvement and the types and styles of their businesses have been re-shaped over time through intricate processes in the host country. These findings further illustrate the point that any comprehensive account of an immigrant group's entrepreneurial behaviour must bring together not only the determinant factors of previous theories 
but also the differences in historical contexts and generations. As a contribution to studies in immigrant entrepreneurship, this research proposes and illustrates the application of a new approach that combines existing theories with historical perspectives.

\section{Notes}

1. There is no official data vis-à-visthe number of Korean-owned garment businesses. However, the main community organisations, such as Korean Association in Argentina and the Chamber of Korean Entrepreneurs in Argentina, typically report and agree that $80-90 \%$ of ethnic Koreans are engaged in the apparel industry.

2. Lee, Areuhentina haninimin 25nyeonsa, 246-247.

3. "Episode 86: Kim Hongyeal", Age of Global Success, KBS Documentary (16/03/2013). http://goo.gl/xNdFJ6 (shortened URL).

4. For research into the role of ethnic resources as well as that of class in the formation and operation of ethnic enterprise, see Light, "Immigrant and ethnic enterprise in North America"; Light and Gold, Ethnic economies; and Light and Rosenstein, Race, ethnicity, and entrepreneurship in urban America.

5. For summaries of middleman minority theory, see Bonacich, "A Theory of Middleman Minorities"; and Zenner, Minorities in the middle: A cross-cultural analysis. In particular, many researchers have indicated that Korean entrepreneurs in the US serve as a middlemen minority because they are caught in vulnerable positions between white providers and low-income black customers. For studies on the middlemen minority characteristics of Korean entrepreneurs in the US, please see Min, Caught in the Middle: Korean Merchants in America's Multiethnic Cities; Min and Kolodny, "The Middleman Minority Characteristics of Korean Immigrants in the United States"; and Yoon, On my own: Korean businesses and race relations in America.

6. For other studies on ethnic enclaves, see Portes, "The social origins of the Cuban enclave economy of Miami"; Portes and Shaffer, "Revisiting the enclave hypothesis: Miami twenty-five years later"; and Zhou, Chinatown: The Socioeconomic Potential of an Urban Enclave.

7. Kloosterman and Rath, Immigrant entrepreneurs, 5.

8. Kloosterman et al., "Mixed embeddedness: (in)formal economic activities and immigrant businesses in the Netherlands."; Kloosterman and Rath, "Immigrant entrepreneurs in advanced economies: mixed embeddedness further explored."; and Rath, Unravelling the rag trade: immigrant entrepreneurship in seven world cities.

9. Kloosterman et al., "Mixed embeddedness: (in)formal economic activities and immigrant businesses in the Netherlands"; Barrett, "Socio-economic and policy dimensions of the mixed embeddedness of ethnic minority business in Britain"; and Kloosterman, "Matching opportunities with resources: a framework for analysing (migrant) entrepreneurship from a mixed embeddedness perspective".

10. Waldinger, "Structural opportunity or ethnic advantage? Immigrant business development in New York".

11. Waldinger, Through the eye of the needle: Immigrants and enterprise in New York's garment trades; Morokvasic, "Immigrants in garment production in Paris and Berlin"; Bonacich and Appelbaum, Behind the label: Inequality in the Los Angeles apparel industry; Green, Ready-towear and ready-to-work: A century of industry and immigrants in Paris and New York; and Rath, Unravelling the rag trade: immigrant entrepreneurship in seven world cities.

12. Jeon, Segyeui Hanminjok (6): Jungnammi, 62.

13. Park, "Nobody remembers the losers: The story of Korean agricultural emigration to South America".

14. Lee 1992, Areuhentina haninimin 25nyeonsa, 130-34; and Son, "Nyeondae Nammi Nongeom Imin: Beurajil, Areuhentina, Paragwai”, 163-64.

15. Lee, Areuhentina haninimin 25nyeonsa, 87-89.

16. Lee, Areuhentina haninimin 25nyeonsa, 187.

17. Lee, Areuhentina haninimin 25nyeonsa, 241. 
18. Light and Bonacich, Immigrant Entrepreneurs: Koreans in Los Angeles, 1965-1982; and Min, Caught in the Middle: Korean Merchants in America's Multiethnic Cities.

19. Morokvasic, "Immigrants in garment production in Paris and Berlin"; Light and Bonacich, Behind the label: Inequality in the Los Angeles apparel industry; Light et al., "Immigrant Incorporation in the Garment Industry of Los Angeles."; and Chin, Sewing women: immigrants and the New York City garment industry.

20. Light and Bonacich, Behind the label: Inequality in the Los Angeles apparel industry.

21. Lee, Areuhentina haninimin 25nyeonsa, 141

22. Lee, Areuhentina haninimin 25nyeonsa, 141. According to Lee, the small grocery shop was another business preference of pioneering Korean immigrants. However, since the early 1990s, the number of Korean grocery shops has declined noticeably, as many of those owners moved into the garment industry.

23. Cited by Lee, Areuhentina haninimin 25nyeonsa, 141.

24. Bialogorski, "La presencia coreana en la Argentina: la construcción simbólica de una experiencia inmigratoria", 97-98.

25. Light and Gold, ethnic economies, 114-115.

26. Yoon, On my own: Korean businesses and race relations in America, 142.

27. Lee, Areuhentina haninimin 25nyeonsa, 249.

28. Lee, Areuhentina haninimin 25nyeonsa, 249.

29. Bialogorski, "La presencia coreana en la Argentina: la construcción simbólica de una experiencia inmigratoria", 296.

30. Lee, Areuhentina haninimin 25nyeonsa, 327.

31. Lee, Areuhentina haninimin 25nyeonsa, 288.

32. Lee, Areuhentina haninimin 25nyeonsa, 288.

33. Waldinger, Through the eye of the needle: Immigrants and enterprise in New York's garment trades; Morokvasic, "Immigrants in garment production in Paris and Berlin"; Bonacich and Appelbaum, Behind the label: Inequality in the Los Angeles apparel industry; Green, Ready-towear and ready-to-work: A century of industry and immigrants in Paris and New York; and Rath, Unravelling the rag trade: immigrant entrepreneurship in seven world cities.

34. Light, Deflecting immigration: Networks, markets, and regulation in Los Angeles, 85-86.

35. Lee, Areuhentina haninimin 25nyeonsa, 197-198.

36. Bialogorski, "La presencia coreana en la Argentina: la construcción simbólica de una experiencia inmigratoria", 295.

37. Lee, Areuhentina haninimin 25nyeonsa, 197-198.

38. In the interview with Hanjun Park, the former president of the Chamber of Korean Entrepreneurs in Argentina used and cited the estimates provided from the same organisation prior to 2014.

39. The most used Korean websites in Argentina are Chamber of Korean Entrepreneurs in Argentina (http://www.iacea.com.ar/gnu/bbs/index.html); and Nammihanuri (http://nammihanuri.com/).

40. Interview with Hanjun Park.

41. Interview with Hanjun Park.

42. Light and Gold, Ethnic economies; and Yoon, "The Changing Significance of Ethnic and Class Resources in Immigrant Business: The Case of Korean Immigrant Business in Chicago".

43. Kim, "Leaving the Ethnic Economy: The Rapid Integration of Second-Generation Korean Americans in New York"; Portes and Zhou, "The New Second Generation: Segmented Assimilation and Its Variants"; Portes and Rumbaut, Legacies: The Story of the Immigrant Second Generation; and Zhou, "Segmented Assimilation: Issues, Controversies, and Recent Research on the New Second Generation".

44. Kim, "Leaving the Ethnic Economy: The Rapid Integration of Second-Generation Korean Americans in New York".

45. Portes and Sensenbrenner "Embeddedness and immigration: Notes on the social determinants of economic action".

46. Light and Bonacich, Immigrant Entrepreneurs: Koreans in Los Angeles, 1965-1982; and Light and Gold, Ethnic economies. 
47. Portes, "Social Capital: Its Origins and Applications in Modern Sociology"; Portes and Landolt, "Social capital: promise and pitfalls of its role in development"; Portes and Sensebrenner, "Embeddedness and immigration: Notes on the social determinants of economic action".

48. Waldinger, Through the eye of the needle: Immigrants and enterprise in New York's garment trades; Morokvasic, "Immigrants in garment production in Paris and Berlin"; Bonacich and Appelbaum, Behind the label: Inequality in the Los Angeles apparel industry; Green, Ready-towear and ready-to-work: A century of industry and immigrants in Paris and New York; and Rath, Unravelling the rag trade: immigrant entrepreneurship in seven world cities.

49. Waldinger, Through the eye of the needle: Immigrants and enterprise in New York's garment trades; Morokvasic, "Immigrants in garment production in Paris and Berlin"; Bonacich and Appelbaum, Behind the label: Inequality in the Los Angeles apparel industry; Green, Ready-towear and ready-to-work: A century of industry and immigrants in Paris and New York; and Rath, Unravelling the rag trade: immigrant entrepreneurship in seven world cities.

\section{Notes on contributors}

Jihye Kim is a Lecturer in Korean Studies in the School of Language and Global Studies at the University of Central Lancashire. A specialist in the migration and settlement experiences of diasporic Koreans, Dr. Kim has published articles on Korean and Korean Chinese (Joseonjok) immigrants in Argentina. Her current research has expanded to include the experiences of these immigrants in Brazil and North Korean immigration in the United Kingdom.

\section{Bibliography}

Barrett, G. "Socio-economic and policy dimensions of the mixed embeddedness of ethnic minority business in Britain." Journal of Ethnic and Migration Studies 27, no. 2 (2001): 241-258.

Bialogorski, M. "La presencia coreana en la Argentina: la construcción simbólica de una experiencia inmigratoria." PhD diss., Universidad de Buenos Aires, 2004.

Bonacich, E. "A Theory of Middleman Minorities.” American Sociological Review 38, no. 5 (1973): 583-594.

Bonacich, E. and Appelbaum, R. P. Behind the label: Inequality in the Los Angeles apparel industry. Berkeley: University of California Press, 2000.

Green, N. L. Ready-to-wear and ready-to-work: A century of industry and immigrants in Paris and New York. Durham: Duke University Press, 1997.

Jeon, G. S. Segyeui Hanminjok (6): Jungnammi [Koreans in the world (6): Latin America]. Seoul: Tongirwon, 1996.

Kim, D. Y. "Leaving the Ethnic Economy: The Rapid Integration of Second-Generation Korean Americans in New York." In Becoming New Yorkers: Ethnographies of the New Second Generation, edited by Philip Kasinitz, John H. Mollenkopf, and Mary C. Waters, 154-88. New York: Russell Sage Foundation, 2004.

Kloosterman, R. "Matching opportunities with resources: a framework for analysing (migrant) entrepreneurship from a mixed embeddedness perspective." Entrepreneurship and Regional Development 22, no. 1 (2010): 25-45.

Kloosterman, R. and Rath, J. "Immigrant entrepreneurs in advanced economies: mixed embeddedness further explored." Journal of Ethnic and Migration Studies 27, no. 2 (2001): 189-202. 
Kloosterman, R. Van Der Leun, J. and Rath, J. "Mixed embeddedness: (in)formal economic activities and immigrant businesses in the Netherlands." International journal of urban and regional research 23, no. 2 (1999): 252-266.

Lee, G. B. Areuhentina haninimin 25nyeonsa [History of 25 years of Korean immigration in Argentina]. Busan: Seonyeongsa, 1992.

Light, I. "Immigrant and ethnic enterprise in North America." Ethnic and Racial Studies 7, no. 2 (1984): 195-216.

Light, I. Deflecting immigration: Networks, markets, and regulation in Los Angeles. New York: Russell Sage Foundation, 2006.

Light, I. and Bonacich, E. Immigrant Entrepreneurs: Koreans in Los Angeles, 1965-1982. Berkeley: University of California Press, 1991.

Light, I. and Rosenstein, C. Race, ethnicity, and entrepreneurship in urban America. New York: Aldine Transactions, 1995.

Light, I. and Gold, S. Ethnic economies. San Diego: Academic Press, 2000.

Min, P. G. Caught in the Middle: Korean Merchants in America's Multiethnic Cities. Berkeley: University of California Press, 1996.

Min, P. G. and Kolodny, A. "The Middleman Minority Characteristics of Korean Immigrants in the United States." In Koreans in the hood: conflict with African Americans, edited by Kwang Chung Kim, 131-155. Baltimore: Johns Hopkins University Press, 1999.

Morokvasic, M. "Immigrants in garment production in Paris and Berlin." Immigration and Entrepreneurship. Culture, Capital and Ethnic Networks, edited by Ivan Light and Parminder Bhachu, 75-95. New Brunswick: Transaction Publishers, 1993.

Park, H. J. "Nobody remembers the losers: The story of Korean agricultural emigration to South America." PhD diss., The Australian National University, 2013.

Portes, A. "The social origins of the Cuban enclave economy of Miami." Sociological perspectives 30, no. 4 (1987): 340-372.

Portes, A. "Social Capital: Its Origins and Applications in Modern Sociology." Annual Review of Sociology 24 (1998): 1-24.

Portes, A. and Sensenbrenner, J. "Embeddedness and immigration: Notes on the social determinants of economic action." American Journal of Sociology 98, no. 6 (1993): 1320-1350.

Portes, A. and Landolt, P. "Social capital: promise and pitfalls of its role in development." Journal of Latin American Studies 32, no. 2 (2000): 529-547.

Portes, A. and Shafer, S. "Revisiting the enclave hypothesis: Miami twenty-five years later." Research in the Sociology of Organizations 25 (2007): 157-190.

Rath, J. Unravelling the rag trade: immigrant entrepreneurship in seven world cities. Oxford: Berg Publishers, 2002.

Turner, J. and Bonacich, E. "Toward a composite theory of middleman minorities." Ethnicity 7 (1980): 144-158.

Waldinger, R. Through the eye of the needle: Immigrants and enterprise in New York's garment trades. New York: New York University Press, 1986. 
Waldinger, R. "Structural opportunity or ethnic advantage? Immigrant business development in New York.” International Migration Review 23, no. 1 (1989): 48-72.

Yoon, I. J. "The Changing Significance of Ethnic and Class Resources in Immigrant Business: The Case of Korean Immigrant Business in Chicago." International Migration Review 25, no. 2 (1991): 303-332.

Yoon, I. J. On my own: Korean businesses and race relations in America. Chicago: University of Chicago Press, 1997

Zenner, W. Minorities in the middle: A cross-cultural analysis. New York: SUNY Press, 1991.

Zhou, M. Chinatown: The Socioeconomic Potential of an Urban Enclave. Philadelphia: Temple University Press, 1995. 
